\title{
Occult hepatitis B virus infection: diagnosis, implications and management?
}

\author{
ANNA SF LOK \\ University of Michigan, Ann Arbor, MI, USA
}

\begin{abstract}
Occult hepatitis B virus (HBV) infection is generally defined as the detection of HBV-DNA in the serum or liver tissue of patients who test negative for hepatitis B surface antigen. In most cases, occult $\mathrm{HBV}$ infection is related to low level HBV infection with subdetectable levels of $\mathrm{HBsAg}$ and not infection with $\mathrm{HBV}$ variants that cannot express $S$ proteins or produce $S$ proteins with aberrant epitopes that are not detected by conventional serological assays. Prevalence of occult HBV infection is related to the overall prevalence of $\mathrm{HBV}$ infection in that country, being more common in persons with prior exposure to HBV. Occult HBV infection has been found in a substantial proportion of patients with cirrhosis and hepatocellular carcinoma but other causes of liver disease are frequently present. Future studies should focus on delineating the pathogenic role of occult $\mathrm{HBV}$ infection and the basis for failure to detect circulating hepatitis B surface antigen.
\end{abstract}

(C) 2004 Blackwell Publishing Asia Pty Ltd

Key words: hepatitis B core antibody, hepatitis B surface antigen, hepatitis B virus DNA.

Occult hepatitis B virus (HBV) infection is generally defined as the detection of HBV-DNA in the serum or liver tissue of patients who test negative for hepatitis B surface antigen (HBsAg). ${ }^{1}$ Key questions regarding occult HBV infection include: How should occult HBV infection be diagnosed? What is the prevalence of occult HBV infection? Does occult HBV infection lead to development of cirrhosis and hepatocellular carcinoma (HCC)? What is the basis for the failure to detect circulating HBsAg? Can occult HBV infection be transmitted? How should patients with occult HBV infection be managed?

\section{HOW SHOULD OCCULT HBV INFECTION BE DIAGNOSED?}

An important observation in patients with occult HBV infection is the low HBV DNA levels: $10^{2-3}$ copies $/ \mathrm{mL}$ in the serum and 0.01-0.1 copy per liver cell. ${ }^{2,3}$ The frequency of detection of HBV DNA is higher in liver tissue than in serum, and more often in frozen than in paraffin-embedded liver tissue. Thus, the material used for HBV DNA detection and the sensitivity of the assay can influence the result. Because of the low amounts of HBV DNA, ultra-sensitive polymerase chain reaction
(PCR) assays, with detection limits of less than 10 copies of HBV DNA per reaction are increasingly used. ${ }^{4}$ It is therefore important to confirm the specificity of the assays and to ensure that all necessary precautions to prevent cross-contamination have been taken. It has been proposed that diagnosis of occult HBV infection be made only when HBV DNA can be detected using at least two sets of primers from different areas of the HBV genome in duplicate assays. ${ }^{1,4}$ Appropriate negative controls must be included in each assay and specificity of the amplification reaction confirmed by sequencing of the amplicons. Precautions to prevent cross-contamination should be used not only during DNA extraction and PCR amplification but also during sample collection and processing.

\section{WHAT IS THE PREVALENCE OF OCCULT HBV INFECTION?}

Prevalence of occult HBV infection is related to the overall prevalence of HBV infection in that country. Occult HBV infection has been reported in $7-19 \%$ of blood donors in endemic areas where $70-90 \%$ of the population had been exposed to HBV, and in $0-9 \%$ in Western countries such as the United States where only 
$5 \%$ of the population had prior exposure to $\mathrm{HBV}^{5-8}$ Prevalence of occult $\mathrm{HBV}$ infection is also related to the presence of markers of HBV exposure. Thus, prevalence of occult $\mathrm{HBV}$ infection is higher in seropositive persons particularly those who are positive for hepatitis B core antibody (anti-HBc) only, than seronegative persons who are negative for anti- $\mathrm{HBc}$ as well as hepatitis B surface antibody (anti-HBs). Several studies reported a high prevalence of occult HBV infection among hepatitis C patients. ${ }^{9,10}$ This is likely related to common risk factors. Prevalence of occult HBV infection is also related to the population studied; rates of detection of serum HBV DNA increasing from 5-50\% among patients with chronic hepatitis to $20-60 \%$ among patients with cirrhosis and HCC., ${ }^{411-13}$ The rates of detection of HBV DNA in liver tissue are higher, up to $60-70 \%$ among patients with chronic hepatitis or HCC. ${ }^{4,14,15}$

\section{DOES OCCULT HBV INFECTION LEAD TO CIRRHOSIS AND HEPATOCELLULAR CARCINOMA (HCC)?}

The pathogenic role of occult HBV infection is unclear. Because occult $\mathrm{HBV}$ infection is more commonly found in patients with cirrhosis or HCC than in those with minimal liver injury, it has been thought that occult HBV infection may result in cirrhosis and HCC. Several studies found that patients coinfected with HBV and HCV have increased risks of HCC compared to those with mono-infection. ${ }^{16,17}$ The two viruses may interact by causing more severe inflammation and accelerated progression to cirrhosis. Alternatively, direct oncogenic effects of these two viruses may be additive or synergistic. Similarly, occult HBV infection can be a cofactor in the development of HCC among patients with alcoholic liver disease or cirrhosis due to other etiologies. Whether occult HBV infection alone causes cirrhosis and HCC is unclear. In studies from western countries, ${ }^{15-17}$ most patients had other causes of liver disease, notably hepatitis $\mathrm{C}$ or chronic alcohol use that may on their own lead to cirrhosis and HCC, but concomitant causes of liver disease are frequently absent in patients from Asian countries. Many of the latter patients may have developed cirrhosis or HCC after decades of chronic HBV infection but had spontaneously cleared HBsAg at the time of presentation (see below).

\section{WHAT IS THE BASIS FOR THE FAILURE TO DETECT CIRCULATING HBSAG?}

Most studies find that occult $\mathrm{HBV}$ infection is related to low level HBV infection with subdetectable levels of $\mathrm{HBsAg}$ and not infection with $\mathrm{HBV}$ variants that cannot express $S$ proteins or variants that express $S$ proteins with aberrant epitopes that cannot be detected by con- ventional serology assays. ${ }^{4}$ While some HBV S variants such as the glycine-arginine substitution at codon 145 (G145R) may be missed by monoclonal antibody based HBsAg assays, most HBV S variants can be detected by polyclonal antibody based serology assays. ${ }^{18}$ Thus, many patients with occult HBV infection could have had overt chronic HBV infection for many years with subsequent spontaneous clearance of HBsAg. ${ }^{19,20}$ Spontaneous clearance of HBsAg in patients with chronic $\mathrm{HBV}$ infection has been reported to occur at the rate of $0.5-1 \%$ per year. ${ }^{21}$ Although the outcome of these patients is improved, HCC has been reported. ${ }^{22}$ Other patients might have transient acute HBV infection in the past with serological recovery. Numerous studies showed that low level HBV DNA can be detected in the liver of these patients more than 10 years later. ${ }^{23} \mathrm{~A}$ recent study from Japan found that inflammation and fibrosis can be detected up to 10 years after serological recovery from acute hepatitis $B .{ }^{24}$ These data, if confirmed, suggest that transient acute HBV infection can result in chronic liver injury, underscoring the importance of $\mathrm{HBV}$ vaccination. In a landmark study by Beasley et al. the incidence of HCC per 100000 per year was 495 and 5 among HBsAg carriers and anti-HBc and/or anti-HBs positive subjects, respectively, compared to 0 among seronegative persons. ${ }^{25}$ The finding of a higher prevalence of occult HBV infection among seropositive persons support the notion that occult $\mathrm{HBV}$ infection is frequently a late phase of overt chronic $\mathrm{HBV}$ infection or serologically recovered acute HBV infection. The explanation for occult HBV infection in seronegative patients is less clear. It is possible that some of these patients had transient acute HBV infection with clearance of $\mathrm{HBsAg}$ initially and decline of anti-HBc and anti-HBs titers to undetectable levels over time. It is also possible that some patients are infected with HBV variants that do not express any HBV proteins. Further studies are needed to determine how frequently this occurs and to characterize these variants.

\section{CAN OCCULT HBV INFECTION BE TRANSMITTED?}

Transmission of HBV infection has been documented from HBsAg negative, anti-HBc positive blood and organ donors. The risk is variable $(0.4 \%-90 \%),{ }^{7,26-28}$ and is highest when livers from anti- $\mathrm{HBc}$ positive donors are transplanted to seronegative recipients. The risk of transmission of $\mathrm{HBV}$ infection from seronegative individuals has not been well studied. Although there have been case reports of such transmission, the overall risk is likely to be negligible.

\section{HOW SHOULD PATIENTS WITH OCCULT HBV INFECTION BE MANAGED?}

There are no data on the use of antiviral therapy in patients with occult HBV infection. The likelihood of 
benefit is low as most patients with occult HBV infection have very low levels of HBV DNA. In the rare patient with persistently high serum HBV DNA levels and absence of other causes of liver disease, antiviral therapy may be considered.

In summary, occult HBV infection is present in a substantial proportion of patients with cirrhosis and HCC; the exact prevalence varies in different parts of the world and with the technique used for detection of HBV DNA. Future studies should delineate the pathogenic role of occult $\mathrm{HBV}$ infection and the basis for the failure to detect circulating HBsAg. Until these critical issues have been addressed, it is premature to advocate testing all HBsAg negative patients with liver disease for occult HBV infection and to recommend treatment with antiviral agents.

\section{REFERENCES}

1 Conjeevaram HS, Lok AS. Occult hepatitis B virus infection: a hidden menace? Hepatology 2001; 34: 204-6.

2 Paterlini P, Poussin K, Kew M, Franco D, Brechot C. Selective accumulation of the $\mathrm{X}$ transcript of hepatitis $\mathrm{B}$ virus in patients negative for hepatitis $\mathrm{B}$ surface antigen with hepatocellular carcinoma. Hepatology 1995; 21: 313231.

3 Cacciola I, Pollicino T, Squandrito G et al. Quantification of intrahepatic hepatitis B virus (HBV) DNA in patients with chronic HBV infection. Hepatology 2000; 31: 50712.

4 Brechot C, Thiers V, Kremsdorf D, Nalpas B, Pol S, Paterlini-Brechot P. Persistent Hepatitis B virus infection in subjects without hepatitis B surface antigen: clinically significant or purely 'occult'? Hepatology 2001; 34: 194203.

5 Matsumoto C, Nishioka K, Oguchi T et al. Detection and quantitation of HBV DNA by semi-nested PCR in donated blood: comparison with HBV serological markers. F. Virol. Meth. 1997; 66: 61-9.

6 Iizuka $\mathrm{H}$, Ohmura $\mathrm{K}$, Ishijima $\mathrm{A}$ et al. Correlation between anti-HBc titers and HBV DNA in blood units without detectable HBsAg. Vox Sang. 1992; 63: 107-11.

7 Douglas DD, Taswell H, Rakela J, Rabe D. Absence of hepatitis B virus DNA detected by polymerase chain reaction in blood donors who are hepatitis B surface antigen negative and antibody to hepatitis $\mathrm{B}$ core antigen positive from a United States population with a low prevalence of hepatitis B serologic markers. Transfusion 1993; 33: 21216.

8 Weinberger KM, Bauer T, Bohm S, Jilg W. High genetic variability of the group-specific-a-determinant of hepatitis $B$ virus surface antigen and the corresponding fragment of the viral polymerase in chronic virus lacking detectable HBsAg in serum. f. Gen. Virol. 2000; 81: 1165-74.

9 Cacciola I, Pollicino T, Squandrito G, Cerenzia G, Orlando ME, Raimondo G. Occult hepatitis B virus infection in patients with chronic hepatitis $\mathrm{C}$ liver disease. $N$. Engl. F. Med. 1999; 341: 22-6.

10 Fukuda R, Ishimura N, Niigaki $M$ et al. Serologically silent hepatitis $\mathrm{B}$ virus coinfection in patients with hepatitis $\mathrm{C}$ virus-associated chronic liver disease: clinical and virological significance. F. Med. Virol. 1999; 58: 201-7.
11 Jilg W, Sieger E, Zachoval R, Schatzl H. Individuals with antibodies against hepatitis $\mathrm{B}$ core antigen as the only serological marker for hepatitis B infection: high percentage of carriers of hepatitis B and C virus. F. Hepatol. 1995; 23: $14-20$.

12 Sheu JC, Huang GT, Shih LN et al. Hepatitis C and B viruses in hepatitis B surface antigen-negative hepatocellular carcinoma. Gastroenterology 1992; 103: 1322-7.

13 Yotsuyanagi H, Shintani Y, Moriya K et al. Virologic analysis of non-B, non-C hepatocellular carcinoma in Japan: frequent involvement of hepatitis B virus. F. Infect. Dis. 2000; 181: 1920-8.

14 Liang TJ, Baruch Y, Ben-Porath E. Hepatitis B virus infection in patients with idiopathic liver disease. Hepatology 1991; 13: 1044-51.

15 Brechot C, Jaffredo F, Lagorce D et al. Impact of HBV, $\mathrm{HCV}$ and GBV-C/HGV on hepatocellular carcinomas in Europe: results of a European concerted action. F. Hepatol. 1998; 29: 173-83.

16 Pollicino T, Squandrito G, Cerenzia G et al. Hepatitis B virus (HBV) maintains its pro-oncogenic properties in case of occult HBV infection. Gastroenterology 2004; 126: $102-10$.

17 Tagger A, Donato F, Ribero ML et al. Case-control study on hepatitis $\mathrm{C}$ virus as a risk factor for hepatocellular carcinoma: the role of $\mathrm{HCV}$ genotypes and the synergism with hepatitis B virus and alcohol. Brescia HCC study. Int. F. Cancer 1999; 81: 695-9.

18 Seddigh-Tonekaboni S, Waters JA, Jeffers S et al. Effect of variation in the common 'a' determinant on the antigenicity of hepatitis B surface antigen. F. Med. Virol. 2000; 60: 113-21.

19 Chung HT, Lai CL, Lok AS. Pathogenic role of hepatitis $B$ virus in hepatitis B surface antigen-negative decompensated cirrhosis. Hepatology 1995; 22: 25-9.

20 Fong TL, Di Bisceglie AM, Gerber MA, Waggoner JG, Hoofnagle JH. Persistence of hepatitis B virus DNA in the liver after loss of HBsAg in chronic hepatitis B. Hepatology 1993; 18: 1313-18.

21 Liaw YF, Sheen IS, Chen TJ, Chu CM, Pao CC. Incidence, determinants and significance of delayed clearance of serum HBsAg in chronic hepatitis B virus infection: a prospective study. Hepatology 1991; 13: 627-31.

22 Huo TI, Wu JC, Lee PC et al. Sero-clearance of hepatitis B surface antigen in chronic carriers does not necessarily imply a good prognosis. Hepatology 1998; 28: 231-6.

23 Reherman B, Ferrari C, Pasquinelli C, Chisari FV. The hepatitis B virus persists for decades after patient's recovery from acute viral hepatitis despite active maintenance of a cytotoxic T-lymphocyte response. Nat. Med. 1996; 2: 1104-8.

24 Yuki N, Nagaoka T, Yamashiro $M$ et al. Long-term histologic and virologic outcomes of acute self-limited hepatitis B. Hepatology 2003; 37: 1172-9.

25 Beasley RP. Hepatitis B virus: the major etiology of hepatocellular carcinoma. Cancer 1988; 61: 1942-56.

26 Hoofnagle JH, Seeff LB, Bales ZB, Zimmerman HJ. Type $\mathrm{B}$ hepatitis after transfusion with blood containing antibody to hepatitis B core antigen. N. Engl. F. Med. 1978; 298: 1379-83.

27 Wachs ME, Amend WJ, Ascher NL et al. The risk of transmission of hepatitis B from HBsAg (-), HBcAb (+), 
HBcIgM (-) organ donors. Transplantation 1995; 59: 230 4.

28 Dickson RC, Everhart JE, Lake JR et al. Transmission of hepatitis B by transplantation of livers from donors posi- tive for antibody to hepatitis B core antigen. The National Institute of Diabetes and Digestive and Kidney Diseases Liver Transplantation Database. Gastroenterology 1997; 113: $1668-74$. 